\title{
Study on Digital Assembly System of Technology and Management for Prefabricated Concrete Buildings
}

\author{
Ning $X U^{1,2, a,{ }^{*}}$ and Guang-Bin WANG ${ }^{1, b}$ \\ ${ }^{1}$ School of Economics and Management of Tongji University, Shanghai, China \\ ${ }^{2}$ Shanghai Ershiye Construction Co.,Ltd., Shanghai, China \\ a123xn@tongji.edu.cn, bob_wang@tongji.edu.cn \\ ${ }^{*}$ Corresponding author
}

Keywords: Digital assembly, System, Technology and management, Prefabricated concrete, BIM.

\begin{abstract}
Based on the comparative analysis of digital assembly between high-end machinery manufacture and construction industry, a system framework of digital assembly of technology and management for prefabricated concrete (PC) buildings was established, and an implementation process of digital assembly of technology and management was proposed correspondingly. Moreover, the main role of Building Information Modeling (BIM) technology in digital assembly for PC buildings was drawn. Taking a real PC project as an example, the application of BIM in digital assembly for PC buildings was demonstrated vividly. It was shown that the system framework of digital assembly for PC buildings includes not only the data source, the process decomposition, the key technology, but also the key management contents such as the process data management, change management, and etc. Digital positioning and digital connection are the most important contents in the implementation process of digital assembly. Using BIM technology, PC components can be assembled accurately and efficiently.
\end{abstract}

\section{Introduction}

As we all know, in the high-end machinery manufacturing products such as aircrafts and automobiles, digital assembly technology has been used for simulating the performance and capabilities of product assembly [1]. The application of digital assembly technology meets the assembly accuracy, quality stability, assembly efficiency and other requirements. With the technology, the product quality improved, and the production cycle shorted.

PC buildings have developed rapidly in recent years [2]. Compared with the traditional buildings, PC buildings changed the traditional manufacturing mode. With the standardized design, industrialized production, mechanized installation and information management, PC buildings ensure the quality of construction, and reduce the intensity of labor, the costs of production, and environmental pollution.

Similar to the machinery manufacturing products, PC buildings are the concrete building structures assembled by reliable connection methods. However, due to the immaturity of existing technologies and standards for PC buildings, PC buildings still have the deficiencies in precision control, quality stability, and etc. There is no relatively mature system of technology and management for guidance [3].

Learning from the digital assembly contents of technology and management for high-end machinery manufacturing products, based on a comparative analysis of digital assembly between high-end machinery manufacturing and construction industry, a system framework of digital assembly of technology and management for PC buildings will be established, and an implementation process of digital assembly of technology and management will be proposed. In addition, a theoretical and practical analysis of the application of BIM technology in digital assembly will be carried out with a real case, and it will provide a reference for the implementation of post similar PC projects.

\section{Comparison of Digital Assembly between Manufacturing and Construction Industry}

Aircraft is one of the most advanced products in the manufacturing industry [4]. In order to build a test cell and support the implementation of digital assembly, the technology for aircraft mainly includes the common key technologies such as positioning, making holes, connection, measurement, and control [5]. 
Compared with the technology of digital assembly for aircraft, the technology of digital assembly for PC buildings was described as follows:

Table1 Comparison of digital assembly between aircraft and PC buildings

\begin{tabular}{|c|c|c|c|}
\hline No. & $\begin{array}{l}\text { Key } \\
\text { technologies }\end{array}$ & Digital Assembly for Aircraft & Digital Assembly for PC Buildings \\
\hline 1 & $\begin{array}{l}\text { Digital } \\
\text { Positioning } \\
\text { Technology }\end{array}$ & $\begin{array}{l}\text { At present, there are three mainly kinds of } \\
\text { digital positioning technologies such as the } \\
\text { digital measurement and positioning } \\
\text { technology, feature positioning technology, } \\
\text { and flexible positioning technology [6]. }\end{array}$ & $\begin{array}{l}\text { At present, digital measurement and } \\
\text { positioning technology is mainly used for PC } \\
\text { buildings. The position of PC components can } \\
\text { be determined by the digital measurement } \\
\text { equipment such as total station and scanner [7]. }\end{array}$ \\
\hline 2 & $\begin{array}{l}\text { Digital } \\
\text { automatic } \\
\text { making hole } \\
\text { technology }\end{array}$ & $\begin{array}{l}\text { According to the numerical control } \\
\text { program from the three-dimensional model } \\
\mathrm{CAD/CAM} \text {, the machine tool automatically } \\
\text { completes the hole- making process. }\end{array}$ & $\begin{array}{l}\text { At present, holes are reserved only in the } \\
\text { processing factory for prefabricated } \\
\text { components. There is no phenomenon of making } \\
\text { hole at the assembly site. }\end{array}$ \\
\hline 3 & $\begin{array}{l}\text { Digital } \\
\text { automatic } \\
\text { riveting } \\
\text { technology }\end{array}$ & $\begin{array}{l}\text { The digital automatic riveting system with } \\
\text { highly integrated in structure and function } \\
\text { from the assembly tool and the riveting } \\
\text { equipment has been used recently. It includes } \\
\text { the automatic riveting machine and NC } \\
\text { bracket. }\end{array}$ & $\begin{array}{l}\text { Generally, post-concrete at the joints, and } \\
\text { bolts or prefabricated stress connections are } \\
\text { used for concrete connections. The steel } \\
\text { reinforcement joints can be connected by steel } \\
\text { sleeve grouting joints, steel slurry anchor lap } \\
\text { joints, welding, mechanical connections, and } \\
\text { reserved holes lap joint connections. }\end{array}$ \\
\hline 4 & $\begin{array}{l}\text { High } \\
\text { efficiency } \\
\text { connection } \\
\text { technology } \\
\text { for long life }\end{array}$ & $\begin{array}{l}\text { Interference with riveting, electromagnetic } \\
\text { riveting, new fasteners, hole extrusion can } \\
\text { improve the fatigue resistance and reliability } \\
\text { of the connection structure }\end{array}$ & $\begin{array}{l}\text { Considering less durability of connection } \\
\text { technology, PE rods and sealant are used for } \\
\text { patchwork. Raising the level of concrete material } \\
\text { for pouring is also a useful method of } \\
\text { connection. }\end{array}$ \\
\hline 5 & $\begin{array}{l}\text { Digital } \\
\text { inspection } \\
\text { and } \\
\text { measurement } \\
\text { technology }\end{array}$ & $\begin{array}{l}\text { Using the digital inspection equipment } \\
\text { (such as coordinate measuring machines, } \\
\text { laser trackers, laser scanners, etc.), 3D } \\
\text { inspection and quality control methods, the } \\
\text { digital inspection technology system can be } \\
\text { established, and it can achieve the goal of } \\
\text { improving the efficiency and quality of } \\
\text { inspections. }\end{array}$ & $\begin{array}{l}\text { Except for the use of digital detection } \\
\text { equipment (such as laser tracker, laser scanners, } \\
\text { etc.), the installation accuracy of the } \\
\text { three-dimensional detection and quality control } \\
\text { means can be verified. } \\
\text { The density of the sleeve grouting needs to be } \\
\text { determined by other concrete and steel detection } \\
\text { technology. }\end{array}$ \\
\hline 6 & $\begin{array}{l}\text { Simulation } \\
\text { technology } \\
\text { for assembly } \\
\text { process. }\end{array}$ & $\begin{array}{l}\text { The process feasibility verification, } \\
\text { auxiliary process improvement, process } \\
\text { training, process parameter checking are } \\
\text { simulated for the position layout, assembly } \\
\text { sequence, assembly path and collaborative } \\
\text { operation. }\end{array}$ & $\begin{array}{l}\text { By using BIM technology, PC buildings can } \\
\text { be pre-assembled to determine the problems } \\
\text { discovered before the construction of hoisting } \\
\text { and component production through the virtual } \\
\text { BIM model. }\end{array}$ \\
\hline 7 & $\begin{array}{l}\text { Multi-system } \\
\text { integration } \\
\text { control }\end{array}$ & $\begin{array}{l}\text { There are many supporting software and } \\
\text { hardware systems, and the data process } \\
\text { methods are abundant. A large number of } \\
\text { interactions and coordination relationships } \\
\text { between data such as design, technology, } \\
\text { measurement, positioning, making holes, and } \\
\text { connection are existing. }\end{array}$ & $\begin{array}{l}\text { There are relatively many supporting software } \\
\text { and hardware systems, and the data process } \\
\text { methods are abundant. There are a large number } \\
\text { of interactions and coordination relationships } \\
\text { among data platforms at different stages of } \\
\text { different specialties. }\end{array}$ \\
\hline
\end{tabular}




\section{System Framework of Digital Assembly for PC Buildings}

Based on the comparison of digital assembly between aircraft and PC buildings, considering the initial data source and the process management of PC buildings, the system framework of digital assembly for PC buildings is described as follows:

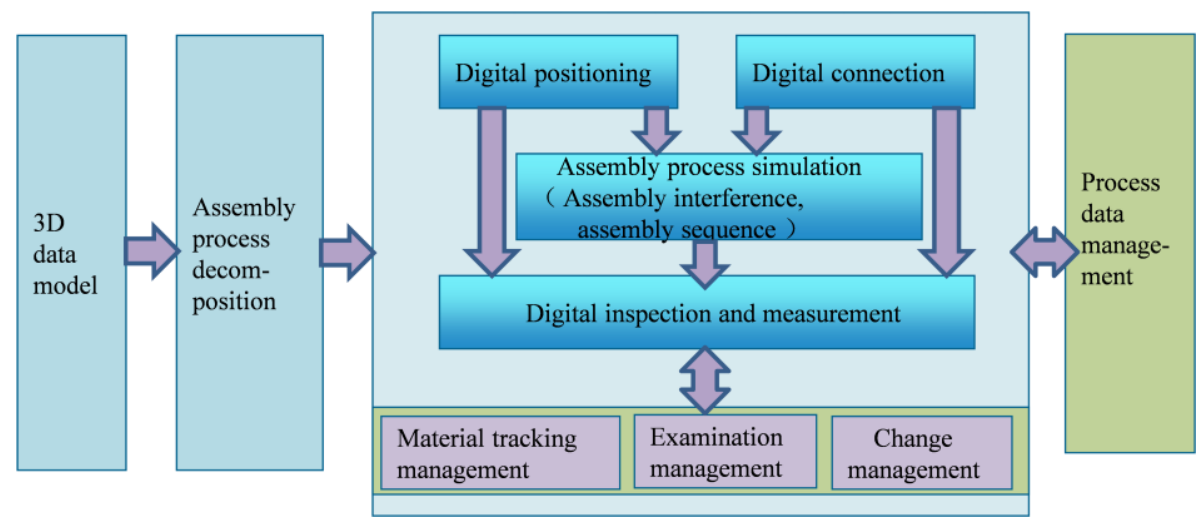

Fig.1 System framework of digital assembly for PC buildings

\section{Implementation Process of Digital Assembly}

Aiming to the phase of assembly for PC buildings, an implementation process should be established to improve the quality of installation and the efficiency of construction. The construction process will be more orderly. The implementation process of digital assembly for PC buildings is established as Fig. 2 .

\section{The Role of BIM in Digital Assembly for PC Buildings}

\section{Improving Inventory and Site Management for PC Components}

At the stage of construction, using BIM technology, the information of the PC components can be determined directly [8]. Checking the necessary contents of the PC components such as the installation location can improve the quality management level and installation efficiency of PC components in the installation process. 


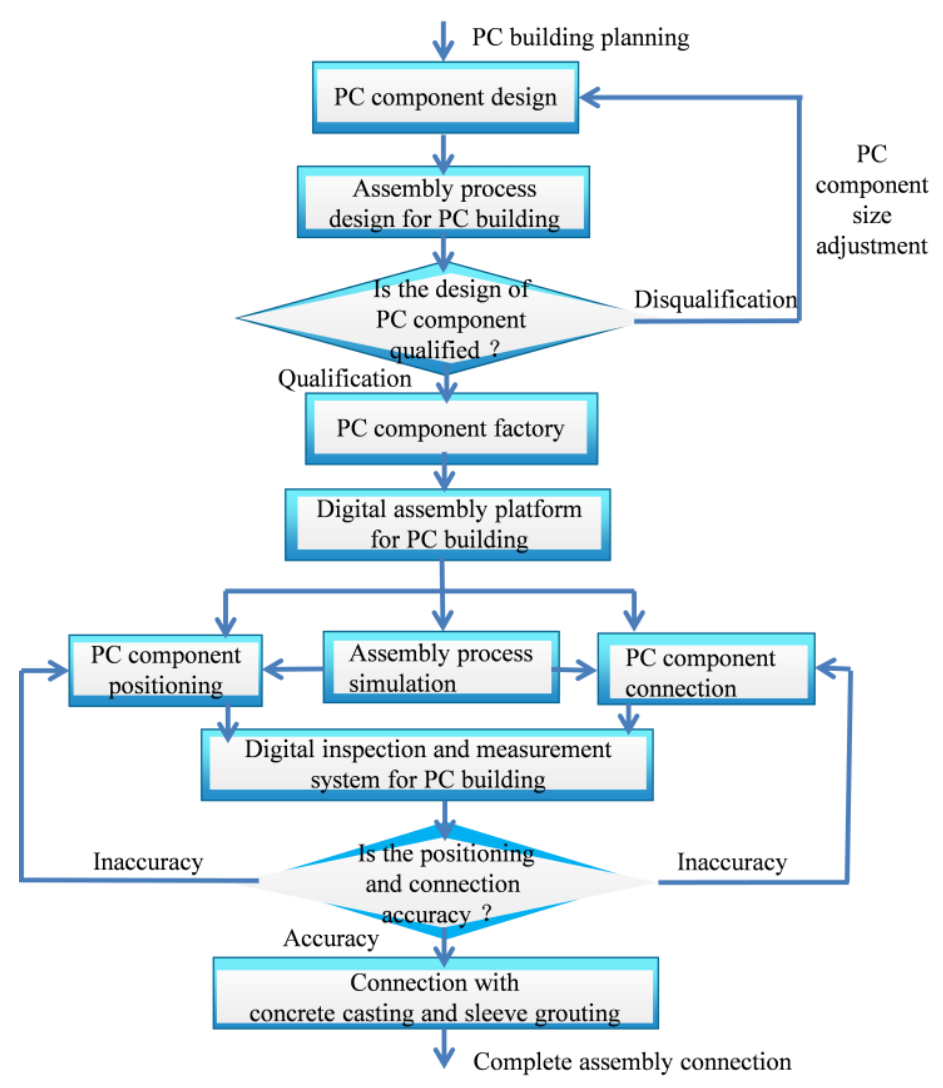

Fig.2 Implementation process of digital assembly

\section{Improving Management Efficiency on Construction Site}

Before construction, BIM technology can be used for simulating the construction phase of PC buildings. With the simulation of lifting and installing process of PC components, the construction process can be optimized. It can also simulate safety accidents at construction sites and improve safety management plans for construction sites.

\section{D Simulation Optimization, Cost Planning}

Introducing time and resource dimensions in the BIM model of PC buildings, "5D-BIM" model can simulate the entire construction process and the input condition of various resources of PC buildings. "Dynamic construction plan" which described the construction process, the schedule plan, the phased capital and the resource investment of the PC buildings can be easily established.

\section{Applications}

\section{Project Overview}

The Gucun PC project in Baoshan District, Shanghai, with a total construction area of approximately $177591.74 \mathrm{~m}^{2}$, consists of 15 single buildings of 15 storeys. The project is prefabricated shear wall structure with $40 \%$ prefabrication ratio. There are 16,185 prefabricated components in this project.

\section{Implementation Situation}

Using the BIM technology, the information of holes and assembly for PC components can be determined accurately. The BIM assembly models in different parts of PC buildings are shown in Fig.3. 


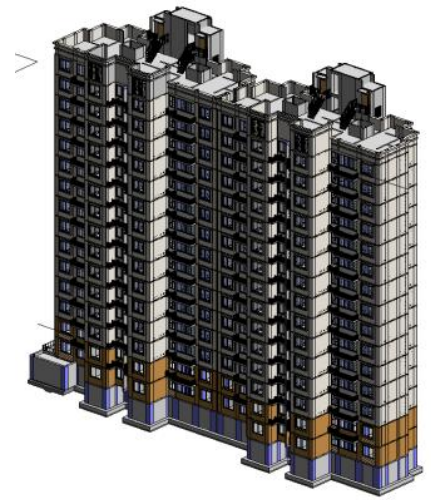

1)The overall mod

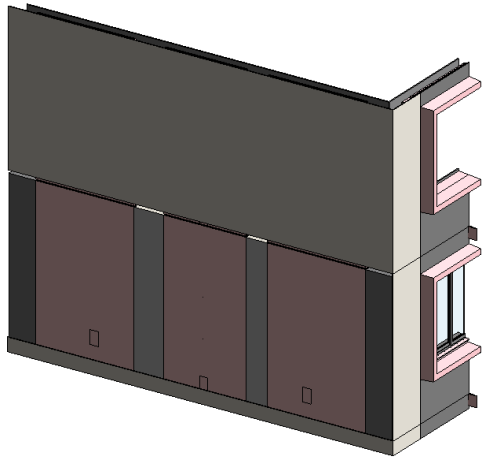

3) The local assembly model

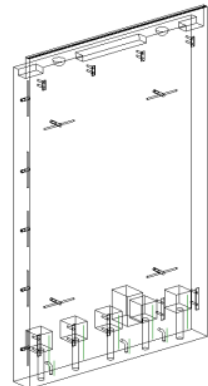

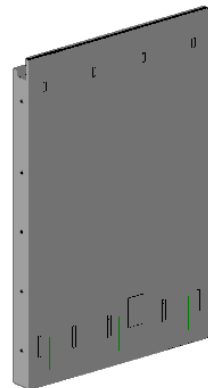

2) The wall model

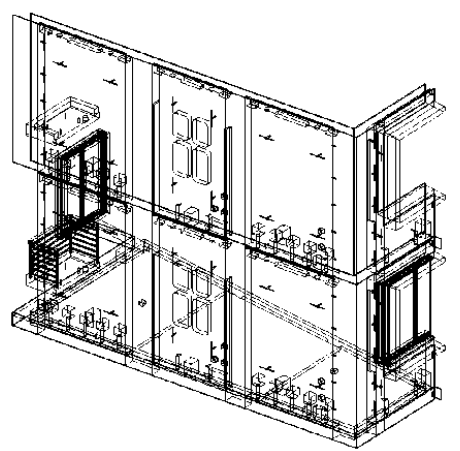

$$
\text { 2) The wall model }
$$




\section{References}

[1] X.M. Chen, S.T. Liu. Development and application of digital assembly technology for aircraft, Aeronautical Manufacturing Technology. 2 (2014) 60-65.

[2] W. Gao. Review of prefabricated concrete structure, Architectural Engineering Technology and Design. 15 (2017) 373-375.

[3] Q.J. Jiang. Summary on development of assembled concrete building both home and abroad, Architecture Technology. 3 (2011) 1074-1077.

[4] Q.P. WANG. Application and prospect of advanced technology in large aircraft design, Aeronautical Manufacturing Technology. 3 (2015) 68-71.

[5] Q.D. Xiao, ZH.Q. Wang, Q. Ma, et al. Research on digital assembly technology for the large size airplane, Manufacturing Information Engineering of China. 3 (2007) 26-29.

[6] W. Han, P.SH. Ma. Research on the application of digital assembly process design and simulation, China Science and Technology Information. 5 (2014) 127-129.

[7] F.Q. Wang. Key points and research on structural construction technique of precast concrete building, Architecture Technology. 1 (2018) 15-21.

[8] J.E. Liu, S. Gao, ZH.L. Guo. Application of BIM technology in fabricated building, Value Engineering. 23 (2017) 161-163. 